\title{
Digital-Pedagogic Training Helping to Develop a Regional System of Life-Long Professional Development
}

\author{
Potasheva O.V. ${ }^{1}$ Kuzmenko M.V. ${ }^{2}$ Plutova M.I. ${ }^{3}$ \\ ${ }^{I}$ Institute of Economics Karelian Research Center RAS (IE KarRC RAS), Petrozavodsk 185030, Russia \\ ${ }^{2}$ Department of Theory and Methods of Primary Education, Institute of Pedagogy and Psychology, Petrozavodsk State \\ University, Petrozavodsk 185910, Russia \\ ${ }^{3}$ Department of Labor Economics and Personnel Management Ural State University of Economicis, Yekaterinburg \\ 620144, Russia \\ "Corresponding author. Email: ovpotash79@gmail.com
}

\begin{abstract}
The article is devoted to the issues of increasing the role of regions in training and forming optimal models for managing the resources of the education system. The main directions of development of educational platforms for distance learning of teachers are presented. The research materials reveal the factor of the changing role of the teacher in the process of digitalization of education and improving the quality of distance education services. Regional practices of using information technologies in the organization of distance learning programs for professional development are described. The analysis of regional features of implementation of distance learning programs is considered by the authors as a condition for determining the ways to improve the available forms of professional development of teachers within the system of life-long professional education. The role of distance education in the implementation of the principle of individualization of training and the possibility of choosing a course depending on the previous professional experience and motivation of students is emphasized.
\end{abstract}

Keywords: digital economy, digital-pedagogic training, regions, teacher, digital skills, continuous pedagogical education

\section{INTRODUCTION}

The process of Informatization of society began in the $70 \mathrm{~s}$ of the last century and under its influence there were cardinal changes in all spheres of life and professional activity of people. Currently, the development of regional economies in a globalizing world increasingly depends on the level of use of digital technologies to increase labor productivity, competitiveness of production and the quality of social services [1]. The solution of these tasks is directly related to the training system and the "realities" of the labor market, because employees do not know how to interact with digital tools and artificial intelligence. It is the educational resources of professional development and professional retraining of specialists that are currently used as a tool for forming digital competencies of employees.

The digitalization of education is becoming an organizational priority of economic development and is reflected in the growth of distance education services and the development of a strategy of "Life-long education" throughout life. The introduction of modern information technologies in all spheres of economic activity presents new challenges to the system of continuous pedagogical development.
In December 2019, Russia approved the basic principles of the national system of professional growth of teachers, including the national system of teacher growth. The purpose of the new requirements is to create and provide objective mechanisms for evaluating professional competencies encourage teachers to continue professional growth, and create a unified Federal system of scientific and methodological support for teachers based on innovative technologies in the implementation of additional professional programs [2]. The indicated tasks are supposed to be solved at the regional level of management of the education system, for example, within the framework of the activities of institutes of advanced training and education development. Among the most effective tools, these can be forms of distance education - advanced training courses, professional retraining of teachers, professional training Increasing the competence of teachers in the use of digital educational technologies is of crucial importance [3]. First of all, because the teacher trains students in information computer skills, i.e. shows responsible use of digital technologies. For example, when you are on the Internet, you need to search for and determine the accuracy of information; to understand what commercial and / or political interests are hidden behind online content; find ways to protect personal information, etc. Secondly, according to foreign and domestic research [4,5], the share 
of education professionals who are limited in their work to the use of ICT in the form of multimedia presentations, e mail and learning management systems is just over $40 \%$ [6]. Students often show a level of digital technology proficiency many times higher than their teachers. Thirdly, the forms of distance education resources contribute to the translation of innovative pedagogical experience through inter -level interaction and regardless of the location of specialists [7].

The purpose of the article is to study the regional features of the implementation of distance learning programs for teachers in order to determine the ways to improve the system of life-long professional education in Russia.

\section{MATERIALS AND METHODS}

According to the authors, the methodology for studying the experience of organizing of organizing distance training and retraining of educational workers involves the use of various theoretical methods. The experience of the Republic of Karelia and the Sverdlovsk region was evaluated in several stages.

At the first stage, we analyzed the official websites of organizations that provide training for teachers in distance form. In the Republic of Karelia, such an organization is the State Autonomous institution of additional professional education "Karelian Institute of education development". In the Sverdlovsk region, the State Autonomous institution of additional professional education "Institute of education development". The information pages of the organizations contained full information about the courses of additional professional education implemented using distance technologies.

At the second stage, the content of educational programs was evaluated according to a number of indicators: the form of training; the amount of training hours; the category of students; the direction of training.

At the third stage, a statistical assessment of the results of educational programs for teachers using distance technologies was carried out. The main sources of information were official reports of institutions. The statistical assessment was carried out for the period from 2017 to 2019. The following indicators were analyzed: the number of training p programs (various forms); the share of programs implemented using distance technologies in the total number of programs; the categories of students in various training programs; the categories of students in the areas of training.

The results of a survey of students are presented in order to highlight the experience of implementing professional development programs for teachers in the Republic of Karelia. The survey is aimed at identifying students ' satisfaction with distance courses.

At the fourth stage of the study, the authors summarized and formulated the advantages of distance training of teachers. Revealed reserves for improving the quality of professional training using distance learning technologies and also identified a number of promising aspects of improving the technologies used.

\section{RESULTS}

\subsection{Literature review}

The study of the formation and development of the system of continuous pedagogical education in Russia [8] revealed the dependence of the level of development of society and the state on the level of development of the national system of teacher training. Among the factors that determine the specifics of teacher training were identified: political, ideological, economic, and sociocultural. As conditions for the development of the system of pedagogical education, the author notes the complexity of educational tasks, the acceleration of the pace of development of society, social shifts, cultural transformations, the development of pedagogical thought and science. The constant satisfaction of the developing needs of the individual in education and providing everyone with opportunities to implement their own educational strategy has become the goal of life-long education. The greatest interest of researchers is associated with the study of actual problems of the development of lifelong education in modern Russia as a special educational cluster of social, scientific, theoretical and practical interest [9]. The work of Dichina N. Y. and Perelomova N. A. focuses on the development of new teacher competencies in the context of the transition to the digital economy [10]. The issues of teaching digital skills and digital literacy of teachers, improving ICT competencies, and opportunities for digitalization of the educational environment in educational institutions of the professional education system have become the subject of research on the specifics of training using forms of online education, personalized and adaptive learning that contributes to the development of personal and professional competencies of teachers $[11,12$, 13].

The current national and foreign experience of studying the level of development of information technologies in the educational process indicates that today a global system of distance education is being formed - one of the most promising and effective systems of the future educational space. Distance education is a method of remote acquisition of professional knowledge (development of a specialty, profile, profession). On educational service platforms, it is most often presented in the form of courses, internships, training programs and advanced training. The analysis of forms of distance education shows that traditional and specific methods, means and forms of education are used in obtaining education but the basis of the educational process is the purposeful and controlled independent work of the student [14]. Among the characteristic features inherent in distance education are [15]: "flexibility" - the student determines and controls the time and pace of training on the program, "modularity" - the choice of necessary courses and the formation of the curriculum based on previous 
experience and needs of the student, "mobility" - the location of the student and his employment are not an obstacle to an effective educational process, "coverage" the number of students does not have a strict quantitative limit, " openness" - provides various forms of online and off-line communication of the student with the accompanying teacher and other participants of educational programs, "self-organization" the synergetic effect of combining and creating pedagogical communities.

In the works $[16,17,18]$, the existing negative factors of implementing distance learning programs are analyzed, as the researchers note that no more than $15 \%$ of students are able to independently master a distance learning course, and therefore the issue of organizing support for distance learning becomes important. It is also necessary to pay attention to evaluating the effectiveness of online learning: tools for evaluating and monitoring knowledge-teachers 'training should not be aimed at getting a "mark", but at achieving concrete results, developing feedback forms and assessing the satisfaction of participants in training, monitoring the application of the knowledge and skills obtained in the professional activities of students.

Modern distance learning is based on the use of a technological environment for transmitting and exchanging information. The most promising is interactive interaction with students through information and communication networks, from which the environment of Internet users is massively distinguished. There are a large number of different distance learning systems, both commercial and freely distributed. In Russia, the most popular system is considered to be "LMS Moodle"(Learning Management System Modular Object Oriented Dynamic Learning Environment [19]. The main advantages of this distance learning system are:

- focus on collaborative learning technologies;

- availability of wide opportunities for communication;

- the ability to create and store the portfolio of each student; - the ability to use any assessment system;

- presentation of the material in any form (picture, video, audio, text);

- a variety of teaching materials (workbooks, lectures, practical exercises, lessons, tests);

- creating own, complex and integrated course in the chosen discipline.

The system supports about 20 activity elements (forums, glossaries, tasks, tests, scorm-packages, databases, etc.), and each element can be used in a wide variety of ways due to its rich settings.

The study of conditions factors of development and formation of professional distance learning in Russia determines its key importance in understanding the essence of life-long teacher training. Considering the spatial, social, and economic differences in resource availability and unsatisfactory demand for life-long teacher education in the country's regions, we consider it appropriate to summarize the experience of regional systems and identify areas for improving distance education services, which will allow participants in the educational process to occupy a competitive niche due to their unique features that are in demand.

Professional development of teachers using distance learning technologies.

The experience in organizing distance professional development and retraining of education workers in the Republic of Karelia

In the system of advanced training of teachers of the Republic of Karelia distance technologies have been applied State Autonomous institution of additional professional education "Karelian Institute of education development" in 2010, in the mode of testing. Distance courses were included in the professional development plan only for certain categories of educational workers, and the programs provided for training lasting no more than 24 hours. From 2010 to 2016, the search for the optimal forms of distance learning was carried out: regulatory, information, and technological bases for distance learning were developed at the Institute, and distance courses were created and tested for almost all categories of educational workers.

This period is characterized by unstable statistics, alternating periods of growth and decline in demand for distance courses, multiple revisions of the content of programs, the volume of programs, forms and methods of training.

Since 2017, the distance learning system at the Institute begins to function normally, there is a steady positive dynamics and a significant increase in the number of advanced training courses implemented using distance technologies. So, in 2017, the share of programs implemented using distance technologies amounted to $22 \%$ of the total number of programs, in $2018-36 \%$, in $2019-$ $57 \%$.

In 2019, distance learning occupies a leading position in the plans for advanced training and retraining of the Institute, and an increasing number of Karelian teachers choose distance training.

Distance learning at the Institute is implemented using the Moodle distance learning system and is carried out in the following forms:

- full - time education;

- full - time and part-time using distance technologies; - correspondence using distance learning technologies.

A table 1 summarizes the number of programs implemented in the above forms for various categories of teachers during 2017-2019. The analysis of the data allows us to conclude that in General there is a stable positive dynamics and an increase in the number of advanced training courses implemented using distance technologies and a gradual decrease in the number of full -time course (figure 1) 
Table 1 The number of programs implemented using distance technology for the period 2017-2019, according to the categories of the audience, $(\%)$

\begin{tabular}{|c|c|c|c|c|c|c|c|c|c|c|c|c|}
\hline \multirow[t]{2}{*}{$\begin{array}{l}\text { Category of the } \\
\text { audience, direction of } \\
\text { study }\end{array}$} & \multicolumn{3}{|c|}{$\begin{array}{l}\text { Number of } \\
\text { programs } \\
\text { (full- time } \\
\text { education) }\end{array}$} & \multicolumn{3}{|c|}{$\begin{array}{l}\text { Number of } \\
\text { programs (full- time } \\
\text { and part -time } \\
\text { using distance } \\
\text { learning } \\
\text { technologies) }\end{array}$} & \multicolumn{3}{|c|}{$\begin{array}{l}\text { Number of } \\
\text { programs (part- } \\
\text { time with the use of } \\
\text { distance learning } \\
\text { technologies) }\end{array}$} & \multicolumn{3}{|c|}{$\begin{array}{c}\text { Percentage of } \\
\text { programs } \\
\text { implemented using } \\
\text { distance learning } \\
\text { technologies from } \\
\text { the total number of } \\
\text { programs }(\%)\end{array}$} \\
\hline & 2017 & 2018 & 2019 & 2017 & 2018 & 2019 & 2017 & 2018 & 2019 & 2017 & 2018 & 2019 \\
\hline Preschool education & 10 & 9 & 9 & 1 & 2 & 0 & 1 & 3 & 7 & 17 & 36 & 44 \\
\hline $\begin{array}{l}\text { General education } \\
\text { (teachers) }\end{array}$ & 45 & 44 & 34 & 5 & 5 & 15 & 2 & 4 & 8 & 13 & 17 & 40 \\
\hline $\begin{array}{l}\text { Secondary professional } \\
\text { education }\end{array}$ & 6 & 4 & 1 & 1 & 2 & 0 & 1 & 1 & 4 & 25 & 43 & 80 \\
\hline $\begin{array}{c}\text { Additional education and } \\
\text { upbringing }\end{array}$ & 8 & 6 & 2 & 1 & 1 & 2 & 1 & 3 & 7 & 20 & 40 & 82 \\
\hline $\begin{array}{l}\text { Ethno-cultural education } \\
\text { (all levels of education) }\end{array}$ & 5 & 3 & 2 & 1 & 1 & 0 & 0 & 2 & 5 & 17 & 50 & 71 \\
\hline $\begin{array}{c}\text { Psychology and pedagogy } \\
\text { of education (all levels } \\
\text { of education) }\end{array}$ & 9 & 6 & 3 & 8 & 4 & 4 & 0 & 2 & 3 & 47 & 50 & 70 \\
\hline $\begin{array}{l}\text { Correctional pedagogy } \\
\text { and special psychology } \\
\text { (all levels of education) }\end{array}$ & 6 & 5 & 8 & 2 & 1 & 0 & 0 & 1 & 2 & 25 & 29 & 20 \\
\hline $\begin{array}{c}\text { Information and } \\
\text { communication } \\
\text { technologies (all levels } \\
\text { of education) }\end{array}$ & 19 & 10 & 2 & 1 & 5 & 0 & 5 & 11 & 25 & 24 & 62 & 93 \\
\hline $\begin{array}{c}\text { Heads and Deputy heads } \\
\text { of educational } \\
\text { organizations (all levels } \\
\text { of education) }\end{array}$ & 9 & 6 & 5 & 2 & 3 & 3 & 0 & 1 & 3 & 18 & 40 & 55 \\
\hline TOTAL & 117 & 93 & 66 & 22 & 24 & 24 & 10 & 28 & 64 & 21 & 36 & 57 \\
\hline
\end{tabular}




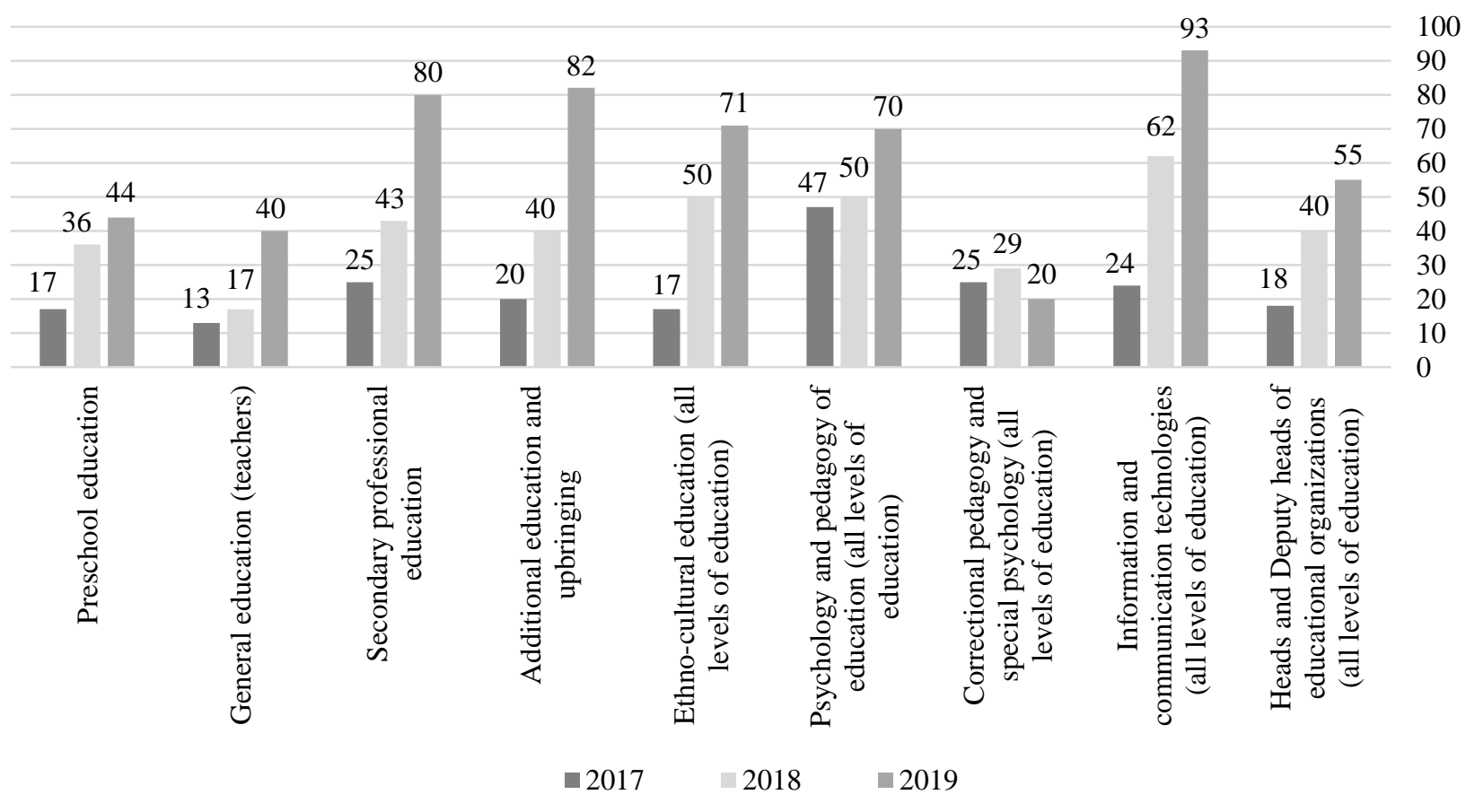

Figure 1 The share of programs implemented using distance learning technologies of the total number of programs (\%)

It should be noted that for certain categories of teachers and training areas there is a significant increase in the number of distance programs and their demand (additional education, secondary professional education, ICT), while for other categories this indicator is small (psychology and pedagogy) and even has a negative dynamics (correctional pedagogy and special psychology). The situation is explained by the specifics of professional activities of teachers, which require more personal contact, a special form of communication and face-to- face communication. Over the years, the Institute's teachers have been actively searching for optimal and effective forms of organizing distance learning.

A survey of students of distance courses, personal conversations with teachers allowed us to come to the following conclusions:

1. More than $91 \%$ of teachers noted the expediency of including elements of personal communication with teachers in distance courses using modern technologies, such as webinars and web consultations. According to teachers, completely distance learning without the possibility of personal, perhaps even distance contact contributes to a decrease in motivation and interest in learning.

2 . The $86 \%$ of teachers consider it necessary both online and offline communication with teachers - recording and subsequent publication of webinars and web consultations in the distance course. The above forms of classes allow working asynchronously, do not requiring time coordination and providing the opportunity to repeatedly return to the material being studied.
3 . The $65 \%$ of teachers note the importance of organizing professional communication of students in distance learning courses, for example, forums, discussions, web conferences.

Therefore, the system of distance learning that has developed by 2019 at State Autonomous institution of additional professional education "Karelian Institute of education development" provides for the following organizational forms (figure 2).

Professional development of teachers using distance education programs : experience of the Sverdlovsk region

The system of retraining and advanced training of the State Autonomous institution of additional professional education "Institute of education development" of the Sverdlovsk region is aimed primarily at identifying and eliminating the professional deficit of teachers. The system includes:

1. Unified information and educational space (including distance learning system).

2. Professional development of municipal and school teams. 3 . Consulting support for teams of municipalities and educational organizations. 


\section{Forms of employment organization}

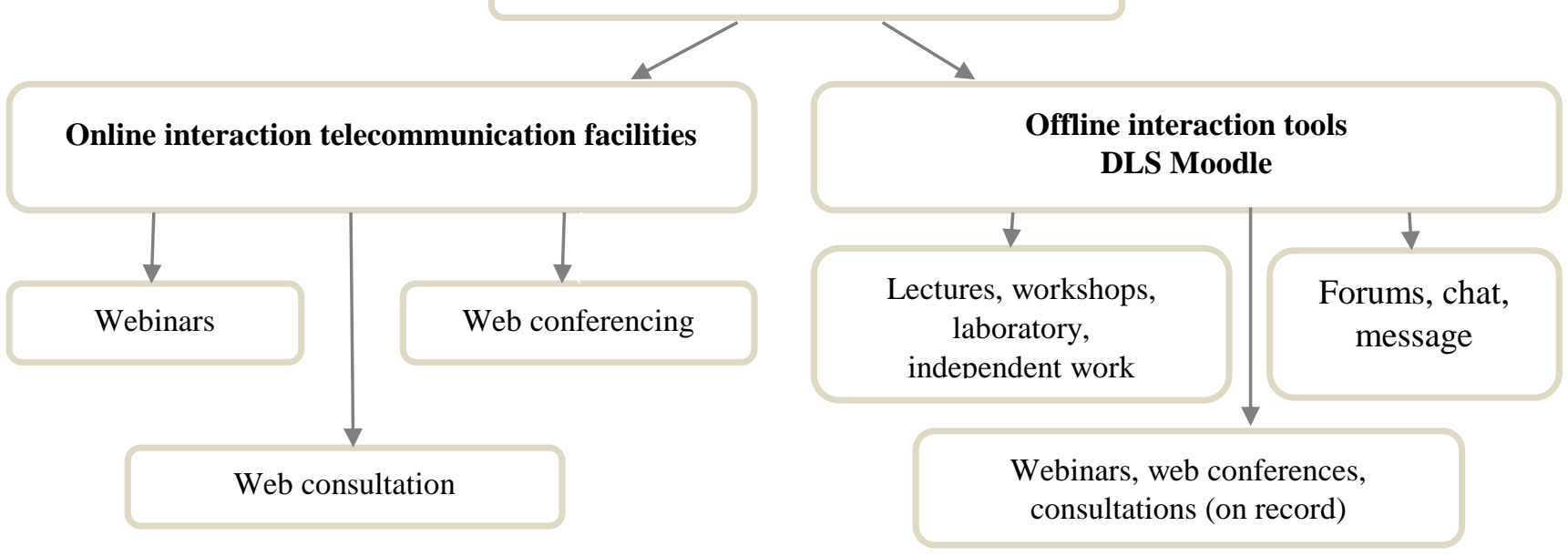

Figure 2 Forms of organization of distance learning in the distance learning system of GAU DPO RK "Karelian Institute for the Development of Education

4. Targeted additional professional development and retraining programs.

5. Productive teaching and management practices.

6. Coaching sessions and project analysis sessions, web consultations, corporate tutoring.

All the above elements of the system are implemented using distance technologies.

Learning using distance technologies is carried out on the e - learning platform-Elearning Server 4G. This system meets all modern requirements: power and scalability (allows connecting an unlimited number of participants to the process); support for training standards (allows using gamification, ratings and competition); usability (intuitive interface and the ability to connect from any device).

The analysis of the annotated catalog of additional professional programs of advanced training and professional retraining for 2019 using distance educational technologies showed:

1. The implemented programs affected all categories of students (teachers, methodologists, administration), taking into account the areas of study (pre- school education; General education; professional education; additional education and upbringing). A total of 51 programs are presented .

2. The $5.9 \%$ - are full-time programs; $78.4 \%$ - are full-time and part-time programs; $15.7 \%$ - are part-time programs.

3. About $12 \%$ of the programs are aimed at developing knowledge about inclusion in education and working with children with disabilities.

4. The $13.7 \%$ - are professional retraining programs with duration of training from 250 to 500 hours; $72.5 \%$ - are programs with duration of training from 16 to 80 hours; $13.8 \%$ - are programs with duration of training from 80 to 250 hours.

The total time spent on training by students of full-time educational programs using distance learning technologies in 2019 amounted to 138,376 people/hours, which is $23 \%$ more than in 2018 and $6.7 \%$ more than in 2017. This trend indicates the growing demand for educational programs using distance technologies among students.

Analysis of the plan of educational activities at the State Autonomous institution of additional professional education "Institute of education development" for 2020 showed the priorities:

- implementation of additional professional life-long programs (from 16 to 250 hours) the form of training is fulltime with the use of remote educational technologies. It is planned to train 8,910 students, which is 2.2 times more than in 2019.

- implementation of additional professional retraining programs ( from $250 \mathrm{~h}$ ours) full-time education with the use of distance educational technologies 75 students are planned to be trained

\section{RESULTS OF THE RESEARCH}

Summarizing the above, it can be summarized that the benefits of life-long education of teachers using distance technologies are obvious:

1. Exclusion of separation from the production process. It is very important for the teacher not to disrupt the educational process of the trainees, and, therefore, there is no way to leave for a long-term professional development.

2. Solving the problem of territorial remoteness. The ability to attract teachers from remote and less economically developed territories to training. Thus, training costs can be minimized.

3. Exchange of experience with colleagues from other territories and regions. The opportunity to conduct international educational programs. 


\section{REFERENCES}

with the peculiarity of the distance education process

1. The difficulty of perceiving online information by older educators. There is no live contact between the subjects of training.

2. The impossibility of absolutely complete control over the knowledge and learning process of students.

3 . The high cost of preparing a distance education course at the initial stage.

4. Temporary absence or poor quality of used technical means (high-speed Internet, modern computer of sufficient power).

In our opinion, many difficulties are solved by using combined methods of professional development using distance technologies, but only on the basis of full -time or part-time training.

\section{CONCLUSIONS}

The authors think significant potential in the use of distance technologies for teaching teachers. However, a number of issues need to be carefully considered in order to improve the technologies used:

1. Administrative aspect: the coordination of the norms of full-time and distance learning. There are no clear algorithms for determining the ratio of the required number of hours of personal presence of the teacher and student, and distance interaction. How to convert full-time study hours to remote ones?

2. Personnel aspect: in the formation of a highly effective distance learning system, personnel with new skills are required. An author-teacher must not only know the subject area of the course and be an active user of PC and the Internet. But at a high level, use visualization techniques, know HTML, text editors, understand the basics of Web design and usability. Students should also be active in using computer technology and be able to work in special software shells in which educational courses are developed. 3. Legal aspect: an educational program using distance learning technologies is a scientific work. Copyright arises at the time of its actual creation. When posted on the Internet or in replication, questions arise about the possible copying, transmission of information and their use by other persons.

\section{ACKNOWLEDGMENT}

Fragment of research made by O. V. Potasheva supported by the Institute of Economics of the Karelian Research Centre of RAS, research work AAAA-A19-119010990087-1.
[1] A. Brolpito, Digital skills and competence, and digital and online learning, European Training Foundation, Turin, 2018, P. 70.

[2] Decree of the Government of the Russian Federation of December 31, 2019. No. 3273-r

[3] A. Yu. Uvarov, S. Wang, C. Kahn et al., Problems and Prospects for the Digital Transformation of Education in Russia and China, II Russian-Chinese Conference of Education Researchers "Digital Transformation of Education and Artificial Intelligence", HSE Publishing House, Moscow, 2019, P. $155 /$

[4] C. Marcelo, C. Yot-Domínguez, From chalk to keyboard in higher education classrooms: Changes and coherence when integrating technological knowledge into pedagogical content knowledge, Journal of Further and Higher Education, 2018, pp. 1-14. DOI:10.1080/0309877X.2018.1429584.

[5] I.V. Slikishina, M.S. Mozharov, A.E. Mozharova, Future teacher training to cope with pedagogical tasks in small group through e-learning, in: Proceedings of International Scientific and Practical Conference on Digital Economy (ISCDE 2019). Atlantis Press. DOI:10.2991/iscde-19.2019.122

[6] M. Bond, V.I. Marín, C. Dolch et al, Digital transformation in German higher education: student and teacher perceptions and usage of digital media, Int $\mathbf{J}$ Educ Technol High Educ 15, 48 (2018). DOI: 10.1186/s41239-018-0130-1

[7] O.V. Potasheva, M.V. Kuzmenko, M.I. Plutova, The effective use of digital technologies in education: positive experience of regional innovation platforms, in: Proceedings of the 1st International Scientific Conference «Modern Management Trends and the Digital Economy: from Regional Development to Global Economic Growth». (MTDE-2019), pp.688-693. DOI:10.2991/mtde-19.2019.140.

[8] D.S. Molokov, Prerequisites for the Formation and Development of Continuing Pedagogical Education, Yaroslavl Pedagogical Bulletin, 2017 (2), pp. 13-18.

[9] I. Deryabina, Continuous Pedagogical Education: Challenges Of The Present, in: Proceedings of EpSBS, 2019, Future Academy, pp. 706-713. DOI:. 10.15405/epsbs.2019.12.75. 
[15] E.R. Devterova, Distance Learning in the System of

[10] N. Yu. Dichina, N. A. Perelomova, Practices of Continuing Professional Education in the Digital World, Domestic and Foreign Pedagogy, 2019. vol. 2, no. 1 (58), pp. $99-110$

[11] V.N. Belkina, T.I. Tarabarina, Professional retraining in the system of continuing teacher education, Yaroslavl Pedagogical Bulletin, 2019 (1), pp. 79-84. DOI: $10.24411 / 1813-145 X-2019-10280$

[12] I. Mitrofanova, Zh. Zherebtsova, A Professional Competence Of Russian Teacher In The Conditions Of Educational Digitalization, in: Proceedings of EpSBS, Future Academy, pp.548-559, DOI: 10.15405/epsbs.2019.12.59

[13] V. I. Kolykhmatov, Development of a system of continuing teacher education in the context of the digitalization of education, Man and Education, no. 4 (57), 2018, pp. 118-121.

[14] O. S. Kryukova, Traditional and "Digital" Pedagogy in the Modern Educational Space, Russia: Trends and Prospects of Development, no. 13-1, 2018, pp. 856-857.
Continuing Professional Education, in: Humanization of Education, 2010, no. 5, pp. 26-32.

[16] S. Prestridge, J. Tondeur, Exploring Elements That Support Teachers Engagement in Online Professional Development, Education Sciences. 2015, 5(3). pp.199219. DOI:10.3390/educsci5030199

[17] E.K. Samerkhanova, Z.U. Imzharova, Organizational and pedagogical conditions for the formation of the readiness of future teachers for project activities in the context of digitalization of education, Vestnik of Minin University, 2018, vol. 6, No2. p. 2. DOI: 10.26795 / 2307-1281-2018-6-2-212.

[18] V.A. Beskrovnaya, E.M. Freidkina, T.I. Vinogradova, Approaches to assessing the quality of distance learning in higher education through the development of tools for monitoring learning outcomes, in: Proceedings of International Scientific and Practical Conference on Digital Economy (ISCDE 2019), DOI: 10.2991/iscde-19.2019.139

[19] A.V. Pisarev, Possibilities of the educational platform Moodle in teaching information technology, Artium Magister, no. 13, 2012, pp. 70-73. 